\title{
Combined Teaching Method: An Experimental Study
}

\author{
Iryna V. Kolesnikova ${ }^{1, *}$ \\ ${ }^{1}$ Department of Pedagogy and Methodology of Primary Education, National Pedagogical Dragomanov University, \\ Kiev 01601, Ukraine \\ *Correspondence: Department of Pedagogy and Methodology of Primary Education, National Pedagogical \\ Dragomanov University, NO: 9 Pirogova Street, Kiev 01601, Ukraine. Tel: 380-044-542-0647. E-mail: \\ Kolesnikovai@list.ru
}

Received: November 28, 2016

Accepted: December 8, 2016

Online Published: December 12, 2016

doi:10.5430/wje.v6n6p51

URL: http://dx.doi.org/10.5430/wje.v6n6p51

\begin{abstract}
The search for the best approach to business education has led educators and researchers to seek many different teaching strategies, ranging from the traditional teaching methods to various experimental approaches such as active learning techniques. The aim of this experimental study was to compare the effects of the traditional and combined (traditional plus active learning) teaching methods in the process of knowledge formation among future primary school teachers. Participants were randomly selected from available Ukrainian $5^{\text {th }}$ year students. After they were pre-tested, randomly divided into two equal groups. The participants in the experimental group were instructed through combined teaching methods, while those in the control group were only taught through traditional lecture. Following the completion of the course, both groups were received their post-test. The results of both groups were equal at the beginning of experiment. An investigation on the post-test indicated that both teaching methods increased the students' post-test scores significantly. Also, the result of post-test scores in the experimental group increased statistically significant than that the control group. This study concluded that active learning plus the traditional teaching method is a feasible alternative to the traditional teaching method only format.
\end{abstract}

Keywords: traditional teaching method; active learning; combined teaching method; knowldege formation

\section{Introduction}

The search for the best approach to business education has led educators to explore many different teaching strategies, ranging from the traditional lecture class to the active learning techniques. It is well known that the Ukrainian education system is inherited from the Soviet Union era and it was adopted without any major changes. In particular in the study plans of pedagogical specializations, the priority was given to the theoretical matters which very often it was held just formally, leaving no impression in the students' minds and had no connection to the future professional activity of the student (Subtelny, 2000), but after independence of Ukraine in 1991 the majority of research of modern Ukrainian researchers have dealt with the problems of moulding the informational competence of future teachers.

Above all, evolution of creative thinking of future elementary school teachers to enhance the formation of knowledge and skills to design a learning process by selecting an appropriate teaching method has not yet been adequately evaluated (Bondar, 2005; Babanskii, 1982). As Kolesnikova (2016a) defines, it's very important to select a well designed method which might be a key to achieve the goal and ensure the effectiveness of the educational process as a whole. Thus, in order to improve the quality of teaching and learning in the classroom, non-traditional strategies such as active learning can be utilized. In addition, the combined (traditional plus modern strategy) teaching method has been suggested by Penner (1984) that must be taken into consideration.

Therefore, the purpose of this study was to compare the effects of the traditional and combined (traditional plus active learning) teaching methods in the process of knowledge formation among future primary school teachers at the Department of Pedagogy and Methodology of Primary Education of the National Pedagogical Dragomanov University, Kiev, Ukraine. 


\subsection{Teaching Method}

The term teaching method refers to the general principles, pedagogy and management strategies used for classroom instruction. In addition, teaching methodology is an essential element in the educational curriculum because it provides the answer to a key question in teacher education.

As Barrett, Bower, and Donovan (2007) define, the teacher centered and student centered approaches are two major types of teaching approaches. It is worth noticing that any teaching method a teacher uses has advantages, disadvantages, and requires some preliminary preparation. Several studies (Barnes \& Blevins, 2003; Morgan, Whorton, \& Gunsalus, 2000) point out that all teaching methods have their strengths and weaknesses. Additionally, for a particular teaching method to be appropriate and efficient it has to be in relation with the characteristics of the learner and the type of learning it is supposed to bring about (Westwood, 2008).

Therefore, effective teaching methods help to activate students' curiosity about a class topic, engage students in learning, develop critical thinking skills, keep students on task, engender sustained and useful classroom interaction, and, in general, enable and enhance the learning of course content (Boundless, 2016).

\subsection{Traditional Teaching Method}

The traditional teaching method, also known as lecture method is very common in education especially at university level. In this education context, the educator can deliver the message via the "chalk-and-talk" method and overhead projector transparencies. This directed instruction model has its foundations embedded in the behavioural learning perspective, which has been used for decades (Skinner, 1938). In addition, the learning mode tends to be passive and the learners play little role in their learning process (Orlich, Harder, Callahan, Kauchak, \& Gibson, 2004).

As Udovic, Morris, Dickman, Postlethwait, and Wetherwax (2002) and Kolesnikova (2016b) state in their study, this approach may not provide students with valuable skills, or even with a body of knowledge that lasts much beyond the end of the term (Udovic et al., 2002). Moreover, it has been found in most universities by many teachers and students that the traditional teaching method in classroom is of limited effectiveness in both teaching and learning.

In this view, the lecture method despite its well documented limitations may not be totally discarded in favour of other teaching approaches (Edlich, 1993; Brockbank \& McGill, 1998). This method of teaching has been more or less similar around the world; the adaptation of teaching methods and styles to different educational contexts has been always an issue for consideration, anyhow, there is a need to transform the lecture method and make it more interactive.

\subsection{Active Learning Pedagogies}

Because of growing competitive demands in modern sociaty educators strive to provide the most productive classroom experience for their students. To achieve this objective, researchers constantly search for new and improved teaching methods. There are a variety of non-traditional teaching methods that effectively conveys information and understanding to students (Martin, 1998). In this regard, active learning has received considerable attention over the past several years (Bonwell \& Eison, 1991). In addition, active learning has added a new dimension to the pedagogies. Furthermore, this methodology has become a preferred way to change the traditional teacher centered classroom into the newer student centered approach to learning. Moreover, active learning instruction is considered as a device to achieve quality, it means that in the higher education the deep learning has changed into an effective form in learning and teaching (Haack, 2008).

According to Shimazoe and Aldrich (2010), active learning has some benefits for students such as having better grades, developing deep learning of materials, promoting positive attitudes toward autonomous learning, and acquiring social skills and self-efficacy beliefs. Berry (2008) postulates that four key elements characterise all active learning approaches: (1) critical thinking, (2) individual responsibility for learning, (3) involvement in open-ended activities, and (4) organization of learning activities by the professor.

In short, active learning requires students to do meaningful learning activities and think about what they are doing (Prince, 2004). Also, active learning is often contrasted to the traditional method where students passively receive information from the instructor.

\section{Methods}

The study was experimental in nature with pre and post-test control group design and was performed at the Department of Pedagogy and Methodology of Primary Education, National Pedagogical Dragomanov University, 
Kiev, Ukraine.

\subsection{Objective of the Study}

A review of literature indicates that a number of previous studies have been conducted on the impact of traditional and combined teaching methods in the study process (Penner, 1984; Morgan et al., 2000). But, in an Ukrainian context no study has been carried out on the issues.

This study, therefore, is an attempt to compare the effects of the traditional and combined (traditional plus active learning) teaching methods in the process of knowledge formation among Ukrainian future primary school teachers. To achieve the above mentioned objective the following research projects were posed as the foci of the current study.

\subsection{Research Hypotheses}

Based on the objective of study the following hypotheses were drafted to be sustained or rejected through analysis of the data.

$\left.\mathrm{H}_{0} 1\right)$ There is no significant difference between the pre and post-test mean scores of students taught through combined (traditional plus active learning) teaching methods.

$\mathrm{H}_{0} 2$ ) There is no significant difference between the pre and post-test mean scores of students taught through traditional teaching methods.

$\mathrm{H}_{0} 3$ ) There is no significant difference between the achievement scores in knowledge of students using traditional and combined (traditional plus active learning) teaching methods.

\subsection{Participants}

Forty future primary school teachers aged $22-25$ both genders were randomly selected from among 132 available Ukrainian $5^{\text {th }}$ years students of special course in desigh theory lessons for primary schools that had already aquired general didactic course as well as methodological knowledge and skills that were integrated during training practice in primary schools.

\subsection{Instruments}

Participants in experimental and control groups were pre and post-tested using the same open ended questions covering the topics of education training subject and concepts from each chapter in order to assess knowledge of the participants before and after applying each teaching method. Then, the participants were pre-tested at the beginnig of the semester, after that participants were randomly divided into two equal groups of 20 each, one experimental and another one control.

For participants in the control group with lecture format, the instructor used PowerPoint slides and delivered in the traditional manner of the lecture style, with no student input/feedback. On the contrary, in the experimental group participants were engaged in the lecture format plus variety of activities, such as reading, writing, discussion, use of modern technology, presentation and seminar that promote analysis, synthesis and evaluation of content.

Following the completion of the course, at the end of semester a post-test was administered to all participants in both groups. The questions were initially explained by the researcher when handed out. They were asked to finish the questions independently based on their own learning conditions for 60 minutes. The differences in the pre and post-test scores were compared to assess improvement under the teaching method being applied in the section. A scoring rubric was used to evaluate students' constructed responses and the maximum score of each test was 20 .

\subsection{Analysis}

The data collected through pre and post-tests were put to statistical analysis using statistic package for social sciences (SPSS) Inc., Chicago, IL., United States, version 13.0 for Windows. In addition to calculating the descriptive statistics, paired samples $t$-test was run to see whether the participants' performances were statistically different on the pre and post-tests. Moreover, 2-tailed $t$-test was run to compare the participants' improvement on pre-test compared to post-test.

\section{Results}

As the first part of analysis, the data of participants' performance was collected and then, a number of descriptive statistics such as mean, median, variance and standard deviation were calculated. The overall results of pre-test in both groups are shown in Table 1. 
Table 1. Results of $t$-test of Overall Scores on Pre-test of Experimental and Control Groups

\begin{tabular}{lllllll}
\hline Pre-test & $\mathrm{N}$ & Mean & $\mathrm{SD}$ & t-value & DF & Sig. (2-tailed) \\
\hline Experimental & 20 & 6.32 & .92 & 0.000 & 38 & 1.000 \\
Control & 20 & 6.32 & 1.32 & & & \\
\hline
\end{tabular}

*Significant at $\alpha=0.05$.

As it can clearly be seen in the Table 1 above, the difference of mean score of both groups at the level of confidence $\alpha=0.05$ was zero. As a result, the mean difference was not significant $(1.000>0.05)$. It's stating that there is no significant difference between two groups and indicating that both groups are absolutely equal at the beginning of experiment.

In order to make sure how much improvement occurred in the scores of experimental group, comparison analysis were performed. The descriptive analyses are shown in Table 2.

Table 2. The Descriptive Statistics for the Pre and Post-test of Experimental Group

\begin{tabular}{clllllll}
\hline Test & $\mathrm{N}$ & Mean & SD & t-value & DF & Correlation & Sig. \\
\hline Pre-test & 20 & 6.3250 & .92160 & -4.386 & 19 & .538 & $.014^{*}$
\end{tabular}

Pair 1

Post-test $\quad 20 \quad 7.9450 \quad 1.95380$

*Significant at $\alpha=0.05$.

According to Table 2 the difference of mean on pre and post-test of experimental group is significant $(\mathrm{P}=.014)$. This simply indicates that students accomplished enough after studying through the combined (traditional plus active learning) teaching methods.

In order to make sure whether the difference was significant or not, the researcher employed a paired samples $t$-test for pre and post-test of experimental group. The results of $t$-test on pre and post-test of experimental group are displayed in Table 3.

Table 3. The Results of the $t$-test on the Pre and Post-test of Experimental Group

\begin{tabular}{|c|c|c|c|c|c|c|c|c|}
\hline & & & $\begin{array}{r}\quad \underline{P r} \\
95 \% \\
9\end{array}$ & $\begin{array}{l}\text { ed Diffe } \\
\text { onfidenc }\end{array}$ & $\begin{array}{l}\text { ices } \\
\text { nterval }\end{array}$ & Differen & & \\
\hline & Mean & SD & SE & & & t-value & $\mathrm{DF}$ & Sig. (2 - tailed) \\
\hline & & & & Lower & Upper & & & \\
\hline Pre \& Post-test & -1.62 & 1.65 & .369 & -2.39 & -8.46 & 4.386 & 19 & 0.000 \\
\hline
\end{tabular}

Based on Table 3 above, the data analysis reveals that the mean difference of scores between pre and post-evaluation (1.62) shows that the experimental group is significantly different when comparing pre and post-test marks ( $\mathrm{P}$ $=.000)$.

According to Table 2 and Table 3 experimental group made significant improvement as the mean difference of pre and post-test mark was significant. This implies that null hypothesis $\mathrm{H}_{0} 1$ was rejected, describing that there is no significant difference between the pre and post-test mean scores of students studying through the combined (traditional plus active learning) teaching methods.

While alternative hypothesis $\mathrm{H}_{1} 1$ which was accepted indicates that there is significant difference between the pre and post-test mean scores of students studying through the combined (traditional plus active learning) teaching methods. 
In this report strong evidence is given to support that the combined (traditional plus active learning) teaching methods is highly effective. To what extent the control group improved their scores, is interesting to consider, the comparison analyses were performed. The descriptive analysis results are shown in Table 4.

Table 4. The Descriptive Statistics for the Pre and Post-test of Control Group

\begin{tabular}{clllllll}
\hline Test & $\mathrm{N}$ & Mean & SD & t-value & DF & Correlation & Sig. \\
\hline Pre-test & 20 & 6.325 & 1.35 & .330 & 19 & .471 & $.036^{*}$
\end{tabular}

Pair 2

Post-test $\quad 20 \quad 6.425$

*Significant at $\alpha=0.05$.

As revealed in Table 4 the control group's mean marks difference between pre and post-test is significant (.036 $<.05)$. The current result indicates that participants in control group also show significant improvement after studying through traditional teaching methods.

Hence, to understand whether this difference is statistically significant or not, the researcher employed another paired samples $t$-test for pre and post-test in control group. The results of $t$-test on pre and post-test of control group are displayed in Table 5.

Table 5. The Results of the $t$-test on the Pre and Post-test of Control Group

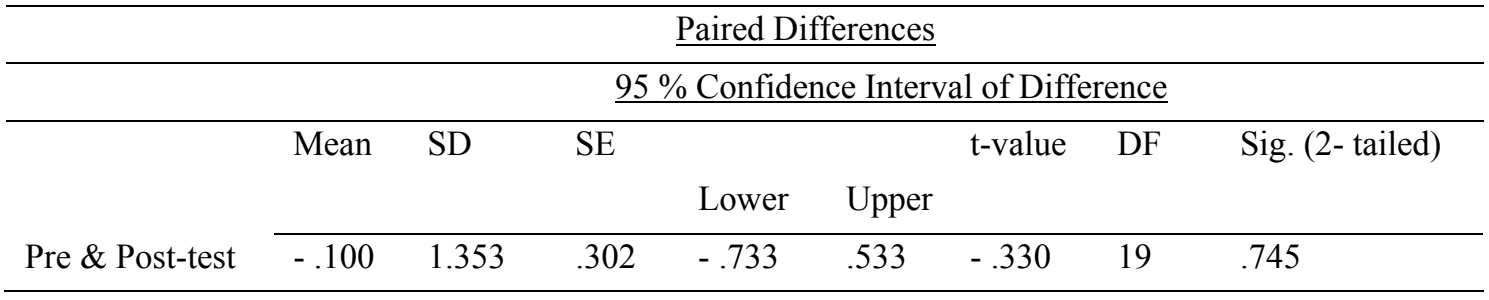

The data analysis in Table 5 above reveals that the mean difference of scores between pre and post-test (.100) shows that the control group has shown significant (.745) improvement in their performance in the post-test as compared to the pre-test. The result implies that the traditional teaching method among this group effective too. The results from Table 4 and Table 5 reject the null hypothesis $\mathrm{H}_{0} 2$ which states that there was no significant difference between the pre and post-test mean scores that taught through traditional teaching method, and alternate hypothesis $\mathrm{H}_{1} 2$ was accepted which reveals that there was significant difference between the pre and post-evaluation mean scores of students taught through traditional teaching method.

The results of data analysis shown in Tables 2 and 5 indicate that both groups made significant progress during the course. Since it is not yet clear which group made more progress and shown improvement in their knowledge in this framework. For this purpose, comparisons of mean scores in post-test are presented in the Table 6.

Table 6. The Results of $t$-test of Overall Scores on Post-test of Experimental and Control Groups

\begin{tabular}{lllllll}
\hline Post-test & $\mathrm{N}$ & Mean & $\mathrm{SD}$ & t-value & DF & Sig. (2-tailed) \\
\hline Experimental & 20 & 7.95 & 1.953 & 2.889 & 38 & $.000^{*}$ \\
Control & 20 & 6.43 & 1.310 & & & \\
\hline
\end{tabular}

*Significant at $\alpha=0.05$.

According to Table 6 above, the mean score of the experimental and control groups were 7.95 and 6.43 respectively, considered greater in experimental group. In addition, based on Tables 3 and 5, the difference of mean scores of both groups in pre and post-test $(1.620-0.1000=1.52)$ shows that post-test performance considered greater in experimental group when compared to the control group. As revealed in Table 6 the difference of mean scores 
between the two groups was significant $(\mathrm{P}=0.006<0.05)$ at the level of confidence $\alpha=0.05$ as set by researcher. Additionally, there is strong evidence to reject the null hypothesis $\mathrm{H}_{0} 3$ because there was no significant difference between the mean scores in knowledge formation. Thus, the alternate hypothesis $\mathrm{H}_{1} 3$ considers significant difference between the mean scores in the knowledge formation applying traditional and combined teaching methods. This implies that combined (traditional plus active learning) teaching method was more effective pedagogy than traditional teaching method for improving knowledge of future primary school teachers.

\section{Discussion}

The obtained results and findings of the present experimental study possess the ability to lead to the conclusions which are undoubtedly of high importance. To this end, after comparing the results of the experimental group performance and those of the control group at the beginning of experiment, both groups were equal in the pre-test.

Lecturing, a time-tested and long-venerated teaching method, remains the most frequent method of instruction in higher education throughout the world (Svinicki \& McKeachie, 2011; Lambert, 2012). The traditional teaching method is generally teacher directed and follows book steps of activities and demonstrations.

In contrast to the traditional teaching method, a more modern view of learning is active learning where students are expected to be active in the learning process by participating in discussions and or collaborative activities (Matiru, Mwangi, \& Schlette, 1995). Active learning accommodates a variety of learning styles, promotes student achievement, enhances learner motivation, changes student attitudes, and basically, causes learners to learn more (Astin, 1997; Fayombo, 2012).

The findings of present study were in agreement with the research of Morgan et al. (2000), Charlton (2006), De Caprariis, Barman, and Magee (2001), Perkins and Saris (2001), Yoder and Hochevar (2005), Hunt, Haidet, Coverdale, and Richards (2003) that demonstrated the use of the lecture combined with discussion improved learning process among students. Concerning the pre and post-test results in present study, the experimenter came to the conclusion that the comparison of pre and post-test scores of experimental and control groups were statistically significant. In this respect, both teaching methods increased the students' post-test scores significantly. About the differences found pertaining to pre and post-tests descriptions, researcher attributes this to the instructors and students academic obligation.

In contrast to present study, the combined method of lecture and group discussion were compared with traditional lecture method, and it was reported that although the students significantly preferred the group discussion to the lecture method, there was no significant difference in the post-test scores of the two groups (Fischer, Jacobs, \& Herbert, 2004). A study by Barnes and Blevins (2003) suggests that active discussion-based methods are inferior to the traditional lecture-based method. In this regard, researcher in the present study attributes this to the students engage in the variety of activities, such as reading, writing, discussion, use of modern technology, presentation and seminar that promote analysis, synthesis and evaluation of content whereas those studies used only group discussion.

Furthermore, in the present study, the result of post-test scores in experimental group increased statistically significant than that control group, this might be mostly due to the amalgamation of the traditional teaching method with active learning activities. This study suggests that knowledge formation can be significantly improved through the use of combined (traditional plus active learning) teaching method among Ukrainian's future primary school teachers.

\subsection{Conclusion}

It could be concluded that some of the criticism and hesitation concerning active learning seems to originate in the belief that these techniques are intended to be alternatives, rather than enhancements of lectures (Faust \& Paulson, 1998). The results of our study highlight that the lecture is efficient way to present pedagogy, but that using lecture as the sole mode of instruction presents less potent than combined (traditional plus active learning) teaching method. As Prince (2004) states, teaching cannot be reduced to formulaic methods and active learning is not the cure for all educational remedies. Hence, the lecture when combined with active learning activities is a feasible alternative to the traditional lecture only format.

\subsection{Limitations and Further Studies}

The maine problem researcher faced in performing this study included difficulty with participants' cooperation due to alteration and adaptation from traditional teacher centered to the combined teaching strategy, which is one way to incorporate active learning activities (Penner, 1984). A lack of proper space for having group discussion sessions 
was another limitation.

In this research, the effect of the combined teaching method in the process of participants' knowledge formation was the chosen focus; thus, for further research skills formation could also be studied, especially according to Kolesnikova (2016a), in the formation of knowledge and skill of future primary school teachers, there should be a close link between theory, methods and teaching techniques.

Additionaly, participants in this study were chosen from 5th year students with didactical and methodological knowledge and skills that were integrated during courses and teaching practice in primary school. As Wildova (2010) states in his study, there are contradictions between the requirements of the primary school teachers and their professional qualities. In this case comparing the combined (traditional plus active learning) and traditional teaching method in the process of the skills formation would be efficient.

\subsection{Recommendations and Pedagogical Implications}

Through showing how the combined (traditional plus active learning) teaching method contributed to the process of knowledge formation, the study hopefully helps in supplying evidence in support of this teaching approach. Although, there currently exists a wide range of pedagogical options designed to match course content, but the selection of an appropriate and effective pedagogy has been a central theme in management education for decades (Roth \& Smith, 2009). Therefore, it is recommended that combined teaching method may be applied for the process of knowledge formation of future primary school teachers. As mentioned by Mehta, Schwartz, and Hess (2012), there are many well-known barriers to educational system change. The teachers, educational leaders and policy makers may arrange and facilitate for combined teaching method's implementation, and the curriculum designers may include combined teaching methods as part of future primary school teachers' training programs in Ukraine. It is believed that the contribution of this research lies in extending the current understanding of both the use and application of combined teaching method as an important and useful pedagogical option in future primary school teachers' education.

\section{Acknowledgements}

The author would like to thank the Dean of the Faculty of Pedagogy and Psychology Prof. Volodymyr Bondar at the National Pedagogical Dragomanov University, Kiev, Ukraine for his great support.

\section{References}

Astin, A. W. (1997). What Matters in College?: Four Critical Years Revisited. San Francisco, CA: Josey-Bass.

Babanskii, J. K. (1982). Оптимизация учебно-воспитательного процесса (методические основы) [Optimization of educational process: Methodical bases]. Moscow: Education.

Barnes, D., \& Blevins, D. (2003). An anecdotal comparison of three teaching methods used in the presentation of microeconomics. Educational Research Quarterly, 27(4), 41-60.

Barrett, K.R., Bower, B. L., \& Donovan, N. C. (2007). Teaching styles of community college instructors. American journal of distance education, 21(1), 37-49. http://dx.doi.org/10.1080/08923640701298738

Berry, W. (2008). Surviving lecture: A pedagogical alternative. College Teaching, 56(3), 149-154. http://dx.doi.org/10.3200/CTCH.56.3.149-153

Bondar, V. I. (2005). Дидактика [Didactic]. 78-96. Kiev: Lybid.

Bonwell, C. C., \& Eison, J. A. (1991). Active Learning: Creating Excitement in the Classroom ASHEERIC Higher Education Report No. 1, George Washington University, Washington, DC.

Boundless Education (2016). Effective teaching strategies help to engage students in learning, develop critical thinking skills, and keep students on task. Retrieved May 28, 2016 From https://www.boundless.com/education/textbooks/boundless-education-textbook/working-with-students-4/teachi ng-strategies-21/effective-teaching-strategies-64-12994/.

Brockbank, A., \& McGill, I. (1998). Facilitating Reflective Learning in Higher Education. Buckingham: Open University Press.

Charlton, B.G. (2006). Lectures are such an effective teaching method because they exploit evolved human psychology to improve learning. Medical Hypotheses, 67(6), 1261-1265. 
http://dx.doi.org/10.1016/j.mehy.2006.08.001

De Caprariis, P., Barman, C., \& Magee, P. (2001). Monitoring the benefits of active learning exercises in introductory survey courses in science: An attempt to improve the education of prospective public school teachers. The Journal of Scholarship of Teaching and Learning, 1(2), 1-11.

Edlich, R. F. (1993). My last lecture. Journal of Emergency Medicine, 11(6), 771-774.

Faust, J. L., \& Paulson, D. R. (1998). Active learning in the college classroom. Journal on Excellence in College Teaching, 9(2), 3-24.

Fayombo, G. A. (2012). Active learning strategies and student learning outcomes among some university students in Barbados. Journal of Educational and Social Research, 2(9), 79-90. http://dx.doi.org/10.5901/jesr.2012.v2n9p79

Fischer, R. L., Jacobs, S. L., \& Herbert, W. N. (2004). Small-group discussion versus lecture format for third-year students in obstetrics and gynecology. Obstetrics and Gynecology, 104(2), 349-53.

Haack, K. (2008). UN studies and the curriculum as active learning tool. International Studies Perspectives, 9(4), 395-410. http://dx.doi.org/10.1111/j.1528-3585.2008.00344.x

Hunt, D. P., Haidet, P., Coverdale, J. H., \& Richards, B. (2003). The effect of using team learning in an evidence-based medicine course for medical students. Teaching and Learning in Medicine, 15(2), 131-139. http://dx.doi.org/10.1207/S15328015TLM1502_11

Kolesnikova, I.V. (2016a). Model of teaching to select the methods of education during general didactical training process for future primary school teachers. [In Ukrainian.] Science and Education a New Dimension. Pedagogy and Psychology, 38(77), 33-37.

Kolesnikova, I.V. (2016b). Future Elementary Teachers' Knowledge and Skills in Selection of Teaching Methods. American Journal of Educational Research, 4(10), 731-735. http://dx.doi.org/10.12691/education-4-9-6

Lambert, C. (2012). Twilight of the Lecture. Harvard Magazine, 114(4), 23-27.

Martin, V. (1998). Developing Managers in the 1990s Public Services: New Requirements in Public Service Management Development. Total Quality Management, $\quad 9(3), \quad$ 279-288. http://dx.doi.org/10.1080/0954412989135.

Matiru, I. B., Mwangi, A. P., \& Schlette, R. (1995). Teach Your Best: A Handbook for University Lecturers. Institute for Socio-cultural Studies (ISOS), University of Kassel: German Foundation for International Development (DSE).

Mehta, J., Schwartz, R. B., \& Hess, F. M. (2012). The Futures of School Reform. Cambridge: Harvard Education Press.

Morgan, R., Whorton, J., \& Gunsalus, C. (2000). A comparison of short term and long term retention: Lecture combined with discussion versus cooperative learning. Journal of Instructional Psychology, 27(1), 53-58.

Orlich, D.C., Harder, R. J., Callahan, R. C., Kauchak, D. P., \& Gibson, H. W. (2004). Teaching Strategies: A Guide To Better Instruction (6th ed.). Boston: Houghton Mifflin.

Penner, J. G. (1984). Why many college teachers cannot lecture: How to avoid communication breakdown in the classroom. Springfield, Ill., USA: Charles C. Thomas.

Perkins, D., \& Saris, N. (2001). A jigsaw classroom technique for undergraduate statistics courses. Teaching of Psychology, 28(2), 111-113. http://dx.doi.org/10.1207/S15328023TOP2802_09

Prince, M. (2004). Does active learning work? A review of the research. Journal of Engineering Education, 93(3), 223-231. http://dx.doi.org/10.1002/j.2168-9830.2004.tb00809.x.

Roth, K. J., \& Smith, C. (2009). Live Case Analysis: Pedagogical Problems and Prospects in Management Education. American Journal of Business Education, 2(9), 59-66.

Shimazoe, J., \& Aldrich, H. (2010). Group work can be gratifying: understanding \& overcoming resistance to cooperative learning. College Teaching, 58(2), 52-57. http://dx.doi.org/10.1080/87567550903418594

Skinner, B. F. (1938). The behavior of organisms: an experimental analysis. 440-457. Oxford, England: Appleton-Century.

Subtelny, O. (2000). Ukraine: a History (3rd ed.). Toronto: University of Toronto Press. 
Svinicki, M. D., \& McKeachie, W. J. (2011). Teaching tips: Strategies, research, and theory for college and university teachers (13th ed.). Belmont, CA: Wadsworth publisher.

Udovic, D., Morris, D., Dickman, A., Postlethwait, J., \& Wetherwax, P. (2002). Workshop Biology: Demonstrating the effectiveness of active learning in an introductory Biology course. BioScience, 52(3), 272-282.

Westwood, P. (2008). What teachers need to know about teaching methods. Camberwell, Vic: ACER Press.

Wildova, R. (2010). Development of Professional Education in Primary School through the Changes in Methodology of Different Curriculum Areas. International Journal of Arts and Sciences, 2(4), 104-110.

Yoder, J., \& Hochevar, C. (2005). Encouraging active learning can improve students' performance on examinations. Teaching of Psychology, 32(2), 91-95. http://dx.doi.org/10.1207/s15328023top3202_2 